\title{
Towards a contribution to sustainable management of a dairy supply chain
}

\author{
Felipe Ungarato Ferreira ${ }^{a}$ (D), Sabine Robra ${ }^{b}$ (D), Priscilla Cristina Cabral Ribeiro ${ }^{\text {c* }}$ (D), \\ Carlos Francisco Simões Gomes ${ }^{\mathrm{c}}$ (D), José Adolfo de Almeida Neto ${ }^{\mathrm{a}}$ (D), Luciano Brito Rodrigues ${ }^{\mathrm{d}}$ \\ anniversidade Estadual de Santa Cruz, llhéus, BA, Brasil \\ bUniversity of Innsbruck, Tirol, Austria \\ cUniversidade Federal Fluminense, Niterói, RJ, Brasil \\ ${ }^{d}$ Universidade Estadual do Sudoeste da Bahia, Itapetinga, BA, Brasil \\ *priscillaribeiro@id.uff.br
}

\begin{abstract}
Paper aims: The paper proposes an enhancement to a focal company in the dairy supply chain, in order to support sustainable performance.

Originality: The authors conclude that previous life cycle assessment (LCA) studies did not recommend for dairy supply chain or use this approach to assess the environmental impacts in this chain.

Research method: A cradle-to-gate attributional life cycle assessment (LCA) study performed in a focal company and considering its transport and processing stages, and three scenarios were proposed as suitable.

Main findings: The impacts derive from energy use and transportation of feedstocks, and the use of cleaning products and certain types of packaging materials. A decrease of $46.5 \%$ of the impact in the photochemical oxidant formation category was achieved.

Implications for theory and practice: The results can identify the different impacts throughout the dairy chain associated with the main product's life cycle, and the possibility of mitigating them.
\end{abstract}

Keywords

Supply Chain Management. Life cycle assessment. Environmental impacts. Dairy industry.

How to cite this article: Ferreira, F. U., Robra, S., Ribeiro, P. C. C., Gomes, C. F. S., Almeida Neto, J. A., Rodrigues, L. B. (2020). Towards a contribution to sustainable management of a dairy supply chain. Production, 30 , e20190019. https://doi/org.10.1590/0103-6513.20190019

Received: Mar. 15, 2019; Accepted: Jan. 30, 2020.

\section{Introduction}

According to the Food and Agriculture Organization of the United Nations (Organisation for Economic Co-operation and Development \& Food and Agriculture Organization of the United Nations, 2018), a new trend is coming in dairy demand in developed and developing countries. In developed countries, per capita consumption of milk solids is projected to grow from $22.2 \mathrm{~kg}$ in $2015-17$ to $23.1 \mathrm{~kg}$ in 2027 , compared to an increase from $10.6 \mathrm{~kg}$ to $13.5 \mathrm{~kg}$ in developing countries. This tendency follows from the positive assessment of dairy fat and a change in taste in developed countries, as well as the increasing globalization of diets, which has influenced consumer decisions in developing countries.

Food waste is associated with loss of abiotic resources such as energy, water, land, and with unnecessary emissions of pollutants into the air, water, and soil (Brancoli et al., 2017). Increasing milk production, population growth and changing consumer habits are resulting in an increased market volume for dairy products, giving 
rise to concerns about possible environmental impacts because of depletion of natural resources and the solid, liquid and gaseous emissions originating from the dairy industry (Rohlfes et al., 2011). In addition, modern food production and advanced logistics increase the threats to food safety (Govindan, 2018).

Before 2010, information technologies were used for optimization or supply chain coordination decision-making. However, companies are now more focused on the sustainability and environmental performance of the food supply chain, because of the increase in these themes in supply chain management (Govindan, 2018). For example, environmental aspects like $\mathrm{CO}_{2}$ emissions and waste reduction have been considered (Zhong et al., 2017).

Even though supply chain integration has been stimulated by the literature, companies are only managing their businesses and failing to share their needs with other chain members. The consequences are economic and management issues, which result in negative environmental consequences (Brockhaus et al., 2013; Corrado et al., 2017). It is mandatory to use consistent data on critical environmental aspects to minimize the adverse environmental impacts of processes (Brockhaus et al., 2013).

Previous studies propose point solutions, not considering the extent of their consequences throughout the chain. In this paper, the LCA method was used to enhance the environmental performance of a focal company in a dairy supply chain. The potential environmental impacts of its main product were assessed, and management solutions at the local level were proposed, resulting in consequences throughout the chain.

Some research questions will be answered after the paper ended:

- What are the environmental impacts of the focal company in the supply chain?

- How sustainable could a company be by reducing the transport distance?

- How sustainable could a company be by reducing the consumption of hygiene products?

- How sustainable could a company be by reducing the transport distance and consumption of hygiene products?

Thus, the use of the LCA method to analyze one stage of the supply chain is justified, as it enables a systemic view of the product life cycle. This facilitates the identification of hotspots, as well the assessment of proposed improvements in the environmental performance of the focal company.

The paper is structured as follows. In the next section, life cycle assessment (LCA), supply chain management (SCM) and sustainability are discussed. Next, the study materials and methods are presented. After that, the results are reported and discussed. The final section provides the conclusions of the study.

\section{Life Cycle Assessment (LCA), Supply Chain Management (SCM) and sustainability}

Environmental issues have received a fair amount of notice in the literature in the last 40 years, and environmental sustainability in particular has begun to garner immense academic and industry attention. However, the practice of relating them to changes in consumer, firm-level and supply-level behavior has only evolved in recent years (Jayaram \& Avittathur, 2015).

Manufacturers have come to realize the potential benefits and importance of cooperative relationships, calling for a wider supply chain management approach. The complex nature of many transactions, especially when trying to drive green supply chain management activities across a firm's supply chain, requires the formation of long-term supply relationships (Roehrich et al., 2017).

\subsection{Sustainable SCM}

The current concept of sustainable development considers at least three key components: economic growth, environmental protection and social equality (Mello et al., 2017). The issue of sustainability in global supply chain management, as focused on these components, has drawn significant attention from various researchers.

Supply chains have a critical aspect, which is the ability to identify sources of supply disruptions and manage risks (Shafiq et al., 2017). Operational risks are related to cost, quality, delivery, and more recently, to sustainability.

According to Kang et al. (2012), the common goal of supply chain management is to generate profit by reducing costs. A company's environmental efforts are perceived as a standard for assessing its business performance.

Supply chains are complex adaptive systems (Carter et al., 2015) that provide a realistic and practical framework for assessing the interconnected environmental, economic and social capital of the energy and material inputs and outputs needed to produce goods and services. 
Since supply chains are also sub-systems of production economies, managers could apply the supply chain resource sustainability (SCRS) framework to aid in the translation of macro-level sustainability targets into actionable productions and operations objectives that are measurable and manageable (Koh et al., 2017). Seles et al. (2016) concluded that environmental pressures were found to propagate across a supply chain from tier to tier.

As environmental awareness grows, firms are expected to expand the scope of their environmental strategies beyond organizational boundaries and to address environmental issues in their supply chains and product life cycles more comprehensively (Martí \& Seifert, 2013). Sustainable business practices can help create wealth for firms and raise the standard of living in emerging markets, while unsustainable economic activities lead to environmental degradation that can threaten an emerging country's long-term prosperity and economic competitiveness (Hsu et al., 2016).

Environmental management is required to improve company performance, mainly in environmentally proactive companies that implement actions for this purpose. Even though this is a requirement, these companies need to invest in specialization and inter-functional link mechanisms to favor environmental management (Pertusa-Ortega et al., 2018).

Managers can be confident that sustainable supply chain initiatives will benefit their firms' reverse logistics. Ecological requirements are key criteria for products and production, particularly for companies that seek ways to ensure economic sustainability by staying competitive and profitable (Hsu et al., 2016).

The three pillars of sustainability are the basis of the triple bottom line approach (3BL), which has been used by researchers and practitioners (Besiou \& Van Wassenhove, 2015). In the context of sustainable supply chain management, it involves looking beyond the traditional economic parameters and making decisions based on life cycle costs, associated environmental and social risks and benefits and broader social and environmental implications (Tchokogué et al., 2018). In the same line, Galal \& Moneim (2016) state that to achieve sustainability in developing countries, the members of the supply chain have to be coordinated, and countries must promote the connections and interactions among the three pillars of sustainability.

A balance among the pillars cannot be achieved without an adequate understanding of how societal and industrial actions or today's decisions affect the environment. The coordination of supply chains is always a challenge, and is even harder in developing countries, which leads to difficulties in buyer-supplier relationships. These countries focus largely on economic benefits, perhaps at the expense of environmental quality (Hutchins \& Sutherland, 2008). Concomitant social effects, which are not included in public policies in these countries, also have to be considered (Hutchins \& Sutherland, 2008). Therefore, there is a need to assess the performance of the whole supply chain in light of the three pillars of sustainability previously mentioned (Galal \& Moneim, 2016). This paper focuses on the environmental dimension, which is not a limitation. We can conclude that sustainable resource practices in a supply chain must be economically viable, but also socially and environmentally responsible for all stakeholders (Koh et al., 2017).

Even though the importance of sustainability in supply chain management has been established, according to Ansari \& Kant (2017), some main barriers to the implementation of these concepts remain. These include the limited integration of partners, poor supplier commitment, less-regulated industries, lack of management commitment and cost. The absence of integration between partners in a supply chain limits their performance, including the assessment of it (Galo et al., 2018).

\subsection{LCA in the dairy industry}

LCA is an important method that helps to achieve proper sustainability by assessing the environmental impacts of product designs (Chang et al., 2014). According to Kulak et al. (2016), chain integration can be promoted by applying LCA as a method to support the assessment of environmental information based on the data collected through the life cycle inventory. Such quantification, called inventory, considers the energy and materials inputs and outputs of the studied product system, relating them to a reference value called the functional unit. After collecting the inventory data, the study proceeds to an environmental impact assessment of the product system.

Life cycle thinking and LCA can identify the challenges along the supply chain, compare options related to food supply-chain optimizations oriented towards sustainable solutions, and assess scenarios related to technology, behavior, under given environmental conditions (Sala et al., 2017).

Molina-Besch (2016), in her study focused on the environmental impacts of packaging in the food industry, remarks, 
Life cycle assessment (LCA) has been used for many years in the industry to determine priorities between different environmental requirements on packaging, and well-executed LCAs deliver valuable input. Another more practical problem of LCAs is that many companies lack resources to perform LCAs (Molina-Besch, 2016, p. 2513).

A great number of LCA studies have been conducted in dairy industries in the past 16 years. These studies have aimed to identify environmental hotspots along with their product's life cycles. Examples are the work of Vagnoni et al. (2017) on sheep's milk ("Pecorino") cheese in Sardinia (Italy); that of Nigri et al. (2014), for cheese in Brazil; that of Djekic et al. (2014), in Serbia, which examined six different dairy products; that of Doublet et al. (2013), on nine dairy products produced in Romania; that of González-García et al. (2013), examining UHT milk in Portugal; and that of Hospido et al. (2003), regarding milk in Spain.

Most of these studies pointed to water and energy consumption, including transportation, as the main contributors to the impacts of the acidification, eutrophication, climate change and photochemical oxidant formation categories in the industry. The same studies showed that milk production is the major contributor to the environmental impacts of a dairy product.

However, these LCA studies did not include any recommendations related to the dairy supply chain. Santos Junior et al. (2017) proposed changes in the volume of hygiene products, without loss of quality and cleaning efficiency, to reduce the impacts of the life cycle of cheese. However, the authors did not suggest any integration for the cheese supply chain, focusing only on environmental performance.

Previous studies proposed point solutions, not considering the extent of their consequences throughout the chain. In this paper, the LCA method was used to enhance the environmental performance of a focal company in a dairy supply chain. The potential environmental impacts of its main product were assessed, and management solutions at the local level were proposed. The use of the LCA method to analyze one stage of the supply chain was justified, as it enabled a systemic view of the product life cycle in identifying hotspots, as well as analyzing proposed improvements in the environmental performance of the focal company.

\subsection{Using LCA for a more sustainable SCM}

LCA and SCM are increasingly integrated because of the growing interest in industrial ecology and sustainable supply chains, leading researchers and practitioners to spend more time with them (Blass \& Corbett, 2018).

Blass \& Corbett (2018), in their paper related to SCM and LCA, understand the demand for studies in environmental impacts from the first. According to these authors, many supply-chain elements occur in batches, including the chemicals needed to clean a process between batches of different products, the energy, and materials consumed while a process is switching from one type of product to another, etc. Some changes in distribution strategy or product mix can, therefore, have nonlinear effects on the corresponding environmental impacts.

Because of the complexity that persists in coordinating the members of the food supply chain, food wastage has increased over the past few years. To achieve sustainable consumption and production (SCP), food industry stakeholders need to be coordinated and to have their views reflected in an optimized manner (Govindan, 2018).

Some authors observe gaps in the literature, relating LCA strengths and emphasizing other aspects, such as social and economic impacts, which can support and give value to the decision-making process (lngwersen et al., 2016). Therefore, according to these authors, LCA is a method that provides an understanding (and reduction) of environmental impacts from consumer products processes in the supply chain.

Food supply chains are structured into different activities: (i) primary production, which includes the agricultural and breeding stages; (ii) transport and storage, which includes the activities that occur after food primary production and before its processing; (iii) processing, which includes all stages of the food process and its output; (iv) distribution, which includes sales and distribution from the factories to the retailers, involving warehouse, inventory and transportation operations; (v) consumption, which includes consumers, restaurants and other places where food is sold after it is cooked; and (iv) end of life, which includes LCA cradle-to-grave studies (Gustavsson et al., 2011; Vazquez-Rowe et al., 2012; Corrado et al., 2017)

\section{Material and methods}

Because of the technological level of its equipment and processing capacity, a medium-size dairy company in Midwest Bahia State in Brazil was chosen to represent the focal company in a dairy supply chain. The analysis presented in this paper discusses the sustainable performance of this focal company (the named dairy plant), not all dairy supply chains. This case study was developed to collect primary data and identify the environmental impacts of this industry within the dairy supply chain. A semi-structured interview with the food engineer 
responsible for plant production allowed for the collection of primary data. The collected data was used to propose different scenarios, corroborating the importance of this method for this supply chain integration.

\subsection{The dairy supply chain structure}

Research on sustainability in food supply chains has been carried out using many approaches (Govindan, 2018). Here, the LCA will be used to manage the environmental aspects related to the dairy supply chain.

The dairy factory is responsible for the economic sustainability of the chain, since it is where the main product takes its final form and gains its market value (Bourlakis et al., 2014). The dairy product chosen for the study of its environmental impacts was Prato cheese. This Brazilian cheese has a Danish origin, similar to Gouda \& Danbo, though it differs in flavor and texture. It accounts for about $20 \%$ of all cheese produced in Brazil (Nepomuceno et al., 2016). Prato cheese has similar production stages to other cheese varieties and the highest economic value when compared to other dairy products (Santos Junior et al., 2017).

The dairy supply chain considered in this study is composed of three segments: i) production of feedstock (dairy farm), upstream; ii) processing, dairy plant (focal company); and iii) marketing, represented by the distribution center, downstream (Figure 1). The horizontal structure of the chain also contains suppliers of inputs to the dairy plant, such as hygiene/cleaning products, materials, and ingredients for processing, firewood for heat generation, packing materials, and others. While Corrado et al. (2017) considered the transport, storage, and processing stages, the present work concentrated on the transport and processing stages to/and in (respectively) the focal company (dairy plant). As mentioned above, the focus of this paper is on the focal company.

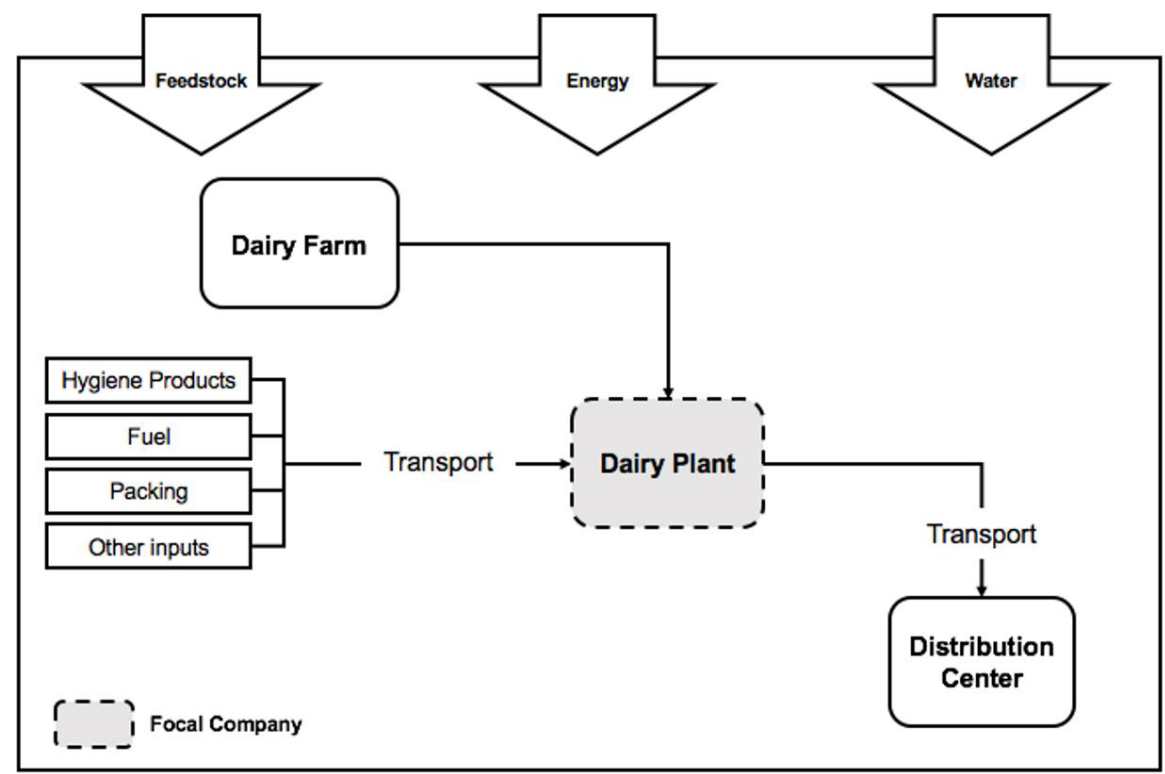

Figure 1. Dairy supply chain structure.

Source: Authors.

When applying LCA as a management tool, the chain's structure can be adjusted to meet its requirements according to the method proposed by Hagelaar \& Van der Vorst (2002). This process starts with the definition of the respective LCA approach according to one of the three strategies- compliance, process, and market-and is oriented to the goals of the studied supply chain. Here, the dairy supply chain's main goal was to achieve compliance with environmental legislation; therefore, a "compliance" strategy was adopted. The "process" and "market" strategies were not considered because of the legal requirements that would have needed to be incorporated to proceed later on with studies focused on prevention of residues in the production processes, and finally to achieve the integration of the stakeholders.

The vast majority of environmental studies on supply chains are qualitative, lacking more specific quantitative content (Wang et al., 2016). In this paper, a qualitative and quantitative approach is applied. 


\subsection{Life cycle assessment}

A cradle-to-gate attributional LCA approach was performed, according to ISO 14040:2006 (International Organization for Standardization, 2006a) and 14044:2006 (International Organization for Standardization, 2006b) standards, containing the following steps: (1) the goal and scope definition; (2) the inventory analysis; (3) the impact assessment; and (4) the interpretation phase. The goal of the LCA was to assess the environmental impacts associated with cheese production to enhance the focal company's (dairy plant's) environmental performance.

The function of the product system is the production of cheese. The functional unit was defined as $1 \mathrm{~kg}$ of Prato cheese, and the system boundary considered to include everything from the raw materials input up to the dairy industry's gate (Figure 2). Because of the multifunctional characteristics of the dairy plant, mass allocation (Table 1) was performed, to distribute the environmental impacts related to the products. Most of the data used in this study were obtained from primary sources, and refer to the consumption of fuel for the production of process heat, electricity consumption, milk and other inputs necessary for cheese production; packing materials; labels; transport of the input materials (distance and type of vehicle); water; and hygiene products. Where primary data were not available, secondary data from databases, e.g., Ecoinvent ${ }^{\circledR}$ (2014), ELCD ${ }^{\circledR}$ (2014), Agri-footprint ${ }^{\circledR}$ (2014), and other research were used.

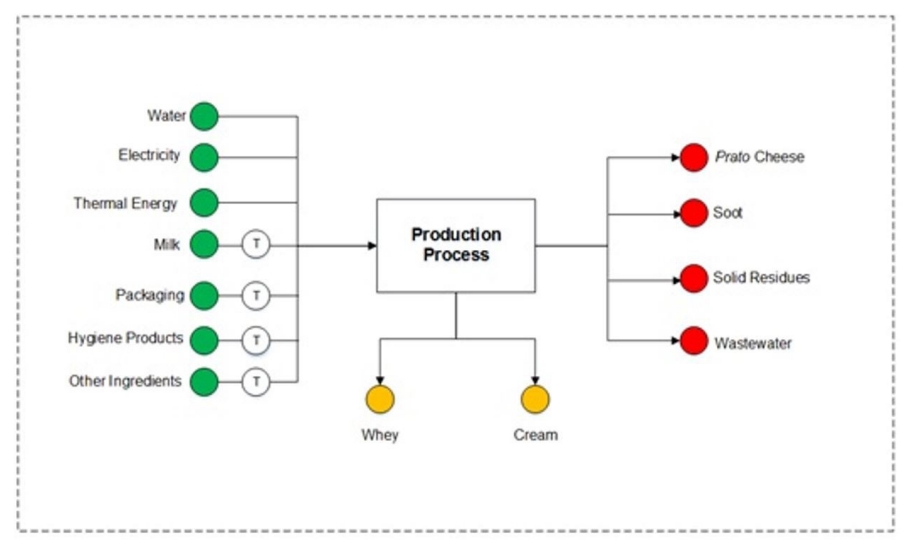

Inputs $\bigcirc$ outpus $\bigcirc$ coproduct $(\mathrm{T}$ Transpot $\square$ Unit Process $\longrightarrow$ Flow

Figure 2. Flowchart from the Prato cheese product system.

Source: Authors.

Table 1. Mass allocation for cheese and other dairy products.

\begin{tabular}{|c|c|c|c|c|c|c|}
\hline \multirow{2}{*}{ Product } & Electricity & Heat & Water & Effluents & $\begin{array}{l}\text { Hygiene } \\
\text { products }\end{array}$ & Transport \\
\hline & kWh/kg (\%) & $\mathrm{MJ} / \mathrm{kg}(\%)$ & $\mathrm{kg} / \mathrm{kg}(\%)$ & $\mathrm{m}^{3} / \mathrm{kg}(\%)$ & kg/kg (\%) & t.km/kg (\%) \\
\hline Pasteurized milk & $0.16(6.90)$ & $2.01(6.82)$ & $0.98(6.27)$ & $0.001(6.25)$ & $0.004(6.06)$ & $0.03(6.38)$ \\
\hline Cream & $0.16(6.90)$ & $2.01(6.82)$ & $0.98(6.27)$ & $0.001(6.25)$ & $0.004(6.06)$ & $0.1(21.28)$ \\
\hline Yogurt & $0.4(17.24)$ & 11.4 (38.66) & $2.63(16.84)$ & $0.003(18.75)$ & 0.011 (16.67) & $0.18(38.30)$ \\
\hline Butter & $0.96(41.38)$ & 7.37 (24.99) & $1.84(11.78)$ & $0.002(12.5)$ & $0.008(12.12)$ & $0.03(6.38)$ \\
\hline Cheese & 0.64 (27.59) & $6.7(22.72)$ & 9.19 (58.83) & $0.009(56.25)$ & 0.039 (59.09) & $0.13(27.66)$ \\
\hline
\end{tabular}

Source: Authors.

According to Djekic et al. (2014) and Santos Junior et al. (2017), the milk life cycle is the main contributor to the impact of the final product (cheese). This study did not consider the environmental burdens of milk as an input to the dairy plant. The relative contributions of each p3articipant in the supply chain and the corresponding impact category were calculated for all the other products considered as inputs to the plant.

The solid residues, soot, and wastewater from the dairy industry considered in this study are sent to the municipal urban cleaning company and municipal sewage, respectively. Therefore, the impacts of those outputs were not considered, as they were considered to have been adequately treated. Furthermore, the paper focuses on the transport and processing stages to/and in the focal company, and not on the transport from the focal company to its partners, even though they are contributing to its disposals. Again, the focus is on the dairy plant. 


\subsubsection{Impact assessment}

The classification of the inventory data according to environmental impact categories occurs in this stage of the LCA. According to Baldini et al. (2017), LCA studies regarding the milk sector should consider a wide range of impact categories. Thus, eight potential environmental impact categories were chosen: climate change (CC, in $\mathrm{kg} \mathrm{CO}_{2 \text { equivalent }}$ ); ozone depletion (OD, in $\mathrm{kg} \mathrm{CFC}-11_{\text {equivalent }}$ ); terrestrial acidification (TA, in $\mathrm{kg} \mathrm{SO}_{2 \text { equivalent }}$ ); freshwater eutrophication (FE, in $\mathrm{kg} \mathrm{P}_{\text {equivalent }}$ ); photochemical oxidant formation ( $\mathrm{POF}$, in $\mathrm{kg}$ NMVOC); particulate matter formation (PMF, in $\mathrm{kg} \mathrm{PM}_{10 \text { equivalent }}$; w water depletion (WD, in $\mathrm{m}^{3}$ ); fossil depletion (FD, in $\mathrm{kg}$ oil equivalent $_{\text {) }}$.

The characterization factors of the method ReCiPe 2008 (Goedkoop et al., 2013) version 1.12, with the hierarchic model $(\mathrm{H})$, were used to correlate the data from the inventory and the environmental impacts associated with the elementary flows. The ReCiPe is the most recent and harmonized indicator approach available in life cycle impact assessment (Pré Sustainability, 2019). The choice of the method and impact categories were based on their environmental relevance and a lesser level of uncertainty associated with the LCA models (Alves et al., 2019). SimaPro ${ }^{\circledR}$ (2014) PhD version 8.0.5.13 was used for processing data and modeling the potential environmental impacts for the product system.

The inventory data for $1 \mathrm{~kg}$ of cheese, as well as the processes and the corresponding database in SimaPro ${ }^{\circledR}$ used for modeling the product system, are shown in Table 2.

Table 2. Inventory, processes, and databases used to produce $1 \mathrm{~kg}$ of Prato cheese.

\begin{tabular}{|c|c|c|c|c|}
\hline $\begin{array}{l}\text { INPUTS/OUTPUTS/ DIRECT } \\
\text { EMISSIONS }\end{array}$ & SIMAPRO ${ }^{\circledast}$ PROCESS & DATABASE & QUANTITY & UNIT \\
\hline Prato cheese & ------ & ------ & 1 & $\mathrm{~kg}$ \\
\hline cream & ------ & ------ & 0.0516 & $\mathrm{~kg}$ \\
\hline \multirow[t]{2}{*}{ whey } & ------ & ----- & 7.9662 & $\mathrm{~kg}$ \\
\hline & INPUTS & & & \\
\hline \multicolumn{5}{|l|}{ Other Ingredients } \\
\hline - Calcium Chloride & Calcium chloride $\{\mathrm{GLO}\} \mid$ market for $\mid$ Alloc Def, $\mathrm{S}$ & Ecoinvent 3 & 0.0067 & $\mathrm{~kg}$ \\
\hline - Salt & Sodium chloride, production mix, at plant, dissolved RER & ELCD & 0.0868 & $\mathrm{~kg}$ \\
\hline Packaging & $\begin{array}{l}\text { Packaging film, low density polyethylene }\{\mathrm{GLO}\} \mid \text { market for | } \\
\text { Alloc Def, S }\end{array}$ & Ecoinvent 3 & 0.0154 & $\mathrm{~kg}$ \\
\hline $\begin{array}{l}\text { Thermal Energy } \\
\text { (Heat produced by combustion of } \\
\text { firewood in a furnace) }\end{array}$ & Heat, onsite boiler, softwood mill average, NE-NC/MJ/RNA & USLCl & 0.1456 & MJ \\
\hline Electricity & Electricity mix, $\mathrm{AC}$, consumption mix, at consumer, $<1 \mathrm{kV} / \mathrm{BR}$ Mass & Agri-footprint & 0.0371 & kWh \\
\hline Water & $\begin{array}{l}\text { Tap water }\{\text { RoW }\} \mid \text { tap water production, underground water } \\
\text { without treatment | Alloc Def, S }\end{array}$ & Ecoinvent 3 & 4.3037 & $\mathrm{~kg}$ \\
\hline \multicolumn{5}{|l|}{ Hygiene products } \\
\hline - Alkaline Detergent & $\begin{array}{l}\text { Sodium hypochlorite, without water, in } 15 \% \text { solution state }\{\mathrm{GLO}\} \mid \\
\text { market for | Alloc Def, S }\end{array}$ & Ecoinvent 3 & 0.0031 & $\mathrm{~kg}$ \\
\hline - Acid Detergent & Hydrogen fluoride $\{\mathrm{GLO}\} \mid$ market for | Alloc Def, S & Ecoinvent 3 & 0.0023 & $\mathrm{~kg}$ \\
\hline - Hydrogen Peroxide & $\begin{array}{l}\text { Hydrogen peroxide, without water, in } 50 \% \text { solution state }\{\mathrm{GLO}\} \mid \\
\text { market for | Alloc Def, S }\end{array}$ & Ecoinvent 3 & 0.0002 & $\mathrm{~kg}$ \\
\hline - Sodium Hydroxide & $\begin{array}{c}\text { Sodium hydroxide }(50 \% \mathrm{NaOH}) \text {, production mix/RER Mass } \\
\text { OUTPUTS }\end{array}$ & Agri-footprint & 0.0023 & $\mathrm{~kg}$ \\
\hline \multicolumn{5}{|l|}{ Solid Residues } \\
\hline - Plastic Residues & Packaging waste, plastic & ----- & 0.0012 & $\mathrm{~kg}$ \\
\hline - Production Residues & Production waste & ------ & 0.0183 & $\mathrm{~kg}$ \\
\hline - Ashes & Wood ashes & ------ & 0.1412 & $\mathrm{~kg}$ \\
\hline - Soot & Soot & ------ & 0.0044 & $\mathrm{~kg}$ \\
\hline Wastewater & Wastewater & ------ & 6.4421 & $\mathrm{~L}$ \\
\hline - Milk Cream & Byproduct & ------ & 0.0516 & $\mathrm{~kg}$ \\
\hline - Whey & Byproduct & ------ & 6.2593 & $\mathrm{~kg}$ \\
\hline \multicolumn{5}{|l|}{ Transports } \\
\hline - Milk Transportation & Transport, single unit truck, diesel powered/US & USLCl & 0.0219 & t.km \\
\hline - Other ingredients Transportation & Transport, single unit truck, diesel powered/US & USLCl & 0.0129 & t.km \\
\hline $\begin{array}{l}\text { - Transport of packaging and hygiene } \\
\text { products }\end{array}$ & Transport, single unit truck, diesel powered/US & USLCl & 0.8260 & t.km \\
\hline
\end{tabular}


The results of both the inventory analysis (storage) in the focal company (dairy plant), and the impact assessment were interpreted based on the objective and the scope initially determined, and included statements of conclusions, limitations, and recommendations.

\subsubsection{Proposed scenarios for mitigating the environmental impacts in the focal company}

Based on the results, the participants in the focal company supply chain with the highest contribution to the impacts were identified. Three possible scenarios for attempting to reduce such impacts were proposed: $\mathrm{S}_{1}$, reduction of the transportation distance by $40 \% ; \mathrm{S}_{2}$, reduction of the consumption of hygiene products by $20 \%$; and $\mathrm{S}_{3}\left(\mathrm{~S}_{1}+\mathrm{S}_{2}\right)$, a grouping of both previous scenarios (40\% reduction of transportation distance $+20 \%$ reduction of hygiene products).

The reduction of the transportation distance in $\mathrm{S}_{1}$ consisted in changing the current supplier of packaging material and hygiene products $(1,420 \mathrm{~km}$ from the dairy plant) to another one close by (828 $\mathrm{km}$ from the dairy plant), using the same truck. This decision assumed the same quality of packaging material and hygiene products. The average final cost of these inputs was decreased because of the logistics cost reduction.

The reduction of $20 \%$ in the use of hygiene products was proposed on the assumption that the quality and prices did not change. Changes in the cleaning technique could therefore contribute to reducing consumption without comprising the cleaning efficiency. According to Santos Junior et al. (2017), cleaning products combinations were not effective in reducing the impacts, altering them by less than $2 \%$. Eide et al. (2003) stated that cleaning technique contributes more to altering the impacts than the type of detergent used. Thus, standardization of cleaning processes according to the model presented by Djekic et al. (2014) was assumed in scenario $\mathrm{S}_{2}$, resulting in a reduction of $20 \%$ in the consumption of hygiene products.

Since the changes in $\mathrm{S}_{1}$ and $\mathrm{S}_{2}$ could happen simultaneously, a third scenario $\left(\mathrm{S}_{3}\right)$ was proposed, which involved merging the two previous scenarios. The results of $\mathrm{S}_{1}, \mathrm{~S}_{2}$, and $\mathrm{S}_{3}$ were compared to each other and to the base scenario $\left(\mathrm{S}_{0}\right)$ to verify changes in the potential environmental impacts considered.

\section{Results and discussion}

\subsection{Environmental impact assessment of cheese}

The impacts of each category for cheese production are shown (Figure 3). The main contributions to the impacts in CC category were due to the transportation of hygiene products (59.18\%); followed by plastic packaging materials (16.06\%), heat production (7.66\%), and sodium chloride (5.18\%). The transportation of the hygiene products was also the main contributor to the other four impact categories (TA, POF, PAM, and FD). Therefore, this was considered a critical point in the production system studied. The hygiene products were the main contributors to the categories OD (hydrogen fluoride, 27.84\%, sodium hypochlorite, 29.89\%,) and EA (hydrogen fluoride, 34.16\%; Sodium hypochlorite, 9.43\%).

The hygiene products were also the second-largest contributor in the TA category (hydrogen fluoride, 8.56\%, sodium hypochlorite, 1.27\%, sodium hydroxide, 0.49\%, and hydrogen peroxide, $0.08 \%$ ) and the third-largest contributor in the WD category (hydrogen fluoride, 5.82\%, sodium hypochlorite, 1.23\%, sodium hydroxide, 0.09\%, and hydrogen peroxide, 0.03\%).

Although the packaging material for the cheese (packaging film) is not the largest contributor, it was present in all assessed impact categories, and was the second-largest contributor in the categories FD (28.15\%), FE (31.12\%), WD (10.52\%), PMF (11.61\%), and POF (11.08\%), and the third-largest contributor in CC (16.06\%), OD $(23.60 \%)$ and TA $(12.00 \%)$. Water consumption for hygiene and sanitation was the largest contributor in the WD category (73.69\%). Also worth mentioning is calcium chloride, which was the third-largest contributor in the categories OD (11.54\%), FE (20.82\%), and FD (1.78\%).

The analysis of the main contributors to the impact categories reveals that some, such as water for cleaning, are directly related to the production process in the dairy plant (focal company). The impacts of other product-related contributors are caused outside the focal company. For example, the impacts of the cheese packaging material (plastic film as primary packing) are associated with the production of this respective input.

Other elementary flows, such as those related to the hygiene products, also caused impacts upstream of the focal company. Their contributions to the impact categories were related to its production, as well as to their usage. Other impacts existed and were caused solely outside the focal company, such as the transportation activities considered in this study (transportation of milk, input materials, packaging materials, and hygiene products). 


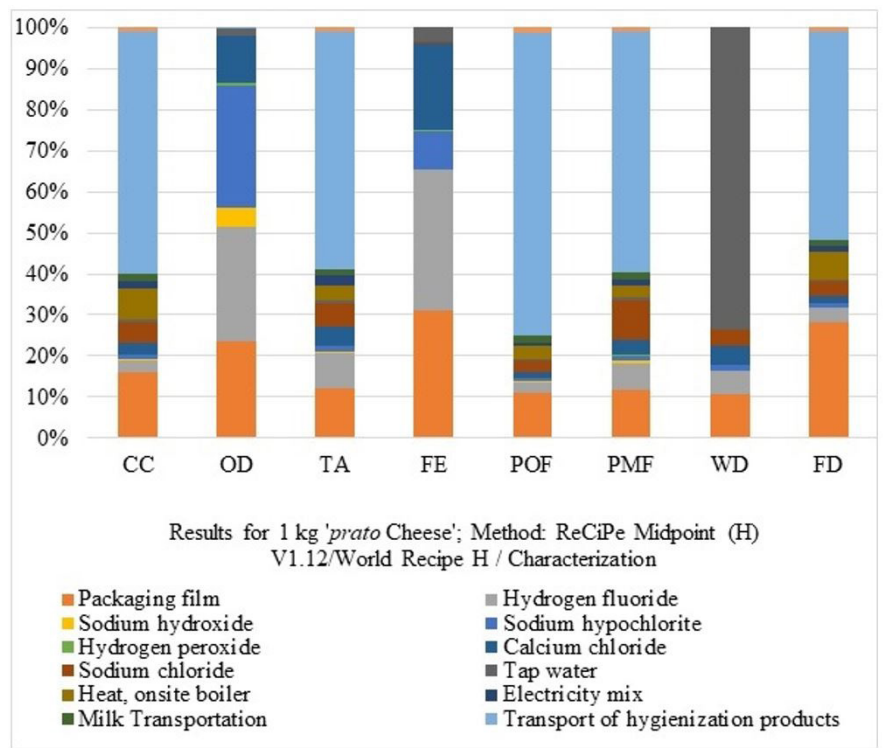

Figure 3. Contribution analysis of the environmental impacts of Prato cheese with mass allocation, ReCiPe Midpoint (H) characterization method. CC - climate change, OD - ozone depletion, TA - terrestrial acidification, FE - freshwater eutrophication, POF - photochemical oxidant formation, PMF - particulate matter formation, WD - water depletion, FD - fossil depletion.

Source: Authors.

Therefore, from the life cycle perspective, the impacts represent not only the activities inside the focal company, but also those along the supply chain. For example, considering the common world water scarcities, including in Brazil, reduction strategies have to be developed for water consumption. The water crisis has direct consequences on the dairy supply chain, mainly because of the general reduction in milk production. The coefficient for water use was $4.30 \mathrm{~L} / \mathrm{L}$ of milk, lower than the values found in the literature (Djekic et al., 2014; Doublet et al., 2013).

For the climate change category, this study identified an emission of $4.07 \mathrm{~kg} \mathrm{CO} 2 \mathrm{eq} / \mathrm{kg}$ of cheese, which is lower than the results obtained by Djekic et al. (2014), who studied seven dairy plants and found a range of 6.73 to $9.47 \mathrm{~kg} \mathrm{CO}$ eq $/ \mathrm{kg}$ of cheese. The results are consistent with those obtained by Doublet et al. (2013), which ranged from 3.24 to $7.76 \mathrm{~kg} \mathrm{CO}$ eq $/ \mathrm{kg}$ of cheese.

As found by Djekic et al. (2014), this study identified fuel consumption as the main contributor to the climate change category in the cheese's life cycle, because of the $\mathrm{CO}_{2}$-emissions by trucks during transportation. However, Doublet et al. (2013) showed that Romania's energy mix was the major contributor to climate change due to the combustion of lignite in the power plant. Santos Junior et al. (2017) indicated that the production of skimmed milk was the main contributor to climate change, mainly due to the use of energy. In the freshwater eutrophication category, the results (0.0002 kg P eq) were lower than those found by Doublet et al. (2013), (0.0004- $0.0010 \mathrm{~kg} \mathrm{P} \mathrm{eq})$, because of the emissions caused by the combustion of lignite in Romanian power plants.

The packaging films are used proportionally to cheese produced. Tiny amounts of plastic film residues are produced in the packing process, so this was not considered a critical point. Among the transportation processes tested in this study, milk transportation did not allow any improvements, as this raw material came from different suppliers. Transport of inputs was also not very flexible, because these items are bought in the county neighboring the dairy plant (focal company). Accordingly, it is only possible to propose changes to the transport of hygiene products and packaging materials, since the supplier of these inputs could be replaced by one closer to the dairy plant while maintaining the same quality and prices.

\subsection{Assessment of scenarios and suggestions for the focal company}

The critical points in the baseline scenario $\left(\mathrm{S}_{0}\right)$ are mainly due to transportation and hygiene products. The results for the three proposed scenarios are presented in Table 3 and discussed. 


\begin{tabular}{lrrrr}
\hline \multirow{2}{*}{ Impact Category } & & \% reduction compared to $\mathrm{S}_{0}$ & $\mathrm{~S}_{2}$ & \\
\cline { 2 - 5 } & \multicolumn{1}{c}{$\mathrm{S}_{1}$} & 0.83 & 37.54 \\
\hline Climate Change & 36.49 & 13.46 & 13.54 \\
Ozone Depletion & 4.01 & 2.28 & 38.19 \\
Terrestrial Acidification & 35,82 & 11.46 & 11.46 \\
Freshwater Eutrophication & 1.94 & 0.74 & 46.49 \\
Photochemical Oxidant Formation & 45.71 & 1.83 & 38.30 \\
Particulate Matter Formation & 36.35 & 1.90 & 1.90 \\
Water Depletion & 0.20 & 0.92 & 32.51 \\
Fossil Depletion & 31.43 & &
\end{tabular}

Source: Authors.

\subsubsection{Reducing the transport distance $\left(\mathrm{S}_{1}\right)$}

$\ln \mathrm{S}_{1}$, a reduction of 35\% in the climate change category can be observed. The reduction in transport distance of $40 \%$ because of the replacement of the original suppliers of packaging material and hygiene products by others closer to the dairy plant reduced the demand for fossil fuel and therefore resulted in lower $\mathrm{CO}_{2}$ emissions.

In the photochemical oxidant formation category, a reduction of $45.7 \%$ can be observed, along with reductions in all the other impact categories. According to Kulak et al. (2016), possible impact reductions depend on the willingness of the members of the supply chain to adopt the suggested measures. Therefore, some form of cooperation in the supply chain is required.

\subsubsection{Reducing the consumption of hygiene products $\left(\mathrm{S}_{2}\right)$}

Scenario $\mathrm{S}_{2}$, (a reduction of $20 \%$ in the consumption of hygiene products), achieved a decrease of $11.5 \%$ in the freshwater eutrophication impact category. Less use of hygiene products also meant reduced purchases of these inputs, resulting in savings for the focal company (dairy plant). If other dairy plants follow the focal company's example, this may cause a decline in the demand for such products, which could eventually reduce phosphate emissions to the water during the production of hydrogen fluoride.

Because of the lack of cooperation within the supply chain, improvements in the life cycles of hydrogen fluoride production were not proposed, and therefore the reduction of environmental impacts was only achieved through the reduced consumption of hygiene products. This scenario resulted in a reduction in all the studied impact categories.

The conventional sanitization method (alkaline/acid) used by the studied focal company (dairy plant), was described by Berlin et al. (2007), and by Djekic et al. (2014). This activity demands constant analysis, optimization, and innovation, because a variety of products and technologies must be applied in order to achieve the required standards of hygiene. Improvements can be achieved by adapting the dosage of the chemical products and by adjusting the heating systems to increase the effectiveness of the solutions. These improvements also affect wastewater quality (Milani et al., 2011).

\subsubsection{Reducing the transport distance and consumption of hygiene products $\left(\mathrm{S}_{3}\right)$}

In the merged scenario $S_{3}\left(S_{1}+S_{2}\right)$, a reduction in all eight analyzed impact categories was achieved relative to the base scenario. The decrease of $37.5 \%$ in the climate change category was related to reduced consumption of fossil fuel, and consequently lower $\mathrm{CO}_{2}$ emissions, because of shorter transportation distances for the input materials. Another relevant result was observed in the photochemical oxidant formation category, with a decrease of 46.5\% of nitrogen oxide emissions, again because of reduced transportation distances.

The results showed that reductions in the environmental impacts of Prato cheese can be achieved not only during the production process, but also through initiatives along the whole supply chain.

$\mathrm{S}_{1}$ yielded reductions of over 30\% (31.43\%-45.71\%) in five of the eight studied categories. In $\mathrm{S}_{2}$, the major reductions were between $11.46 \%$ and $13.46 \%$, in the categories OD and FE, respectively, where no relevant reductions occurred in $S_{1}$. In $S_{3}$, the magnitude was maintained, and where $S_{1}$ and $S_{2}$ resulted in reductions in different categories, $S_{3}$ resulted in major reduction potential in more categories than $S_{1}$ and $S_{2}$ individually. $\ln \mathrm{S}_{3}$, seven of the eight categories saw relevant reductions of over $11 \%$ compared to $\mathrm{S}_{0}$, confirming a synergistic 
effect in the improvement of the environmental performance of cheese through reducing the consumption of hygiene products and transportation.

\section{Conclusions}

The results show the contribution of LCA method to the enhancement of the sustainable performance of a focal company in a dairy supply chain. This contribution occurs through the impact assessment of the company's main product, and by the identification and proposal of improvements that can be managed by the dairy industry, with no expansion with the modeling of the upstream and downstream segment.

This shows possibilities for the application of LCA results, for example in the selection of suppliers, which should comply with certain environmental standards, for example benchmarking references, to be considered. This is only one perspective on an integrated analysis of a dairy supply chain.

Even though some improvements might not be implemented because of the almost non-existent cooperation among the members of the studied dairy supply chain, LCA as a tool for decision-making can also strengthen the integration of the chain, because it provides important information, not only for the focal company, but also for all the other stakeholders. To achieve this, a cooperation structure needs to be developed for the supply chain: the roundtable needs to be avoided, and advances towards a multi-focused approach to the chain structure have to be made. This includes major partnership contracts among stakeholders for many of the decision-making functions, and can result in a win-win situation in the dairy product supply chain.

The public perception of environmental impacts caused by food processing and production often diverges from the facts revealed by scientific studies. The environmental management of supply chains can improve this situation by using necessary data and quality information supplied by research, not only as a basis for their decision-making processes, but also for marketing purposes.

We can recommend further research with that broadens the scope of analysis, such as from the focal company to the upstream of the supply chain, i.e., the dairy industry and its first- and second-tier suppliers (the main ones, which influence the process directly). New research can investigate the downstream of the supply chain, i.e., from the focal company to its first- and second-tier customers. A third option is a study applying LCA in the entire supply chain, from the milk producer to the retailers. A fourth way to study this method is by applying it in another kind of food or beverage supply chain.

The paper has as a limitation the use of a unique case study to collect data, which did not compromise the quality of research. It is possible to investigate other chains or even other dairy companies using the method presented.

\section{References}

Agri-footprint ${ }^{\circledR}$. (2014). LCA DataBase. The Netherlands: Agri-Footprint.

Alves, E. C., Soares, B. B., Almeida Neto, J. A., \& Rodrigues, L. B. (2019). Strategies for reducing the environmental impacts of organic mozzarella cheese production. Journal of Cleaner Production, 223, 226-237. http://dx.doi.org/10.1016/j.jclepro.2019.03.006.

Ansari, Z. N., \& Kant, R. (2017). A state-of-art literature review reflecting 15 years of focus on sustainable supply chain management. Journal of Cleaner Production, 142(4), 2524-2543. http://dx.doi.org/10.1016/j.jclepro.2016.11.023.

Baldini, C., Gardoni, D., \& Guarino, M. (2017). A critical review of the recent evolution of Life Cycle Assessment applied to milk production. Journal of Cleaner Production, 140(2), 421-435. http://dx.doi.org/10.1016/j.jclepro.2016.06.078.

Berlin, J., Sonesson, U., \& Tillman, A. M. (2007). A life cycle based method to minimise environmental impact of dairy production through product sequencing. Journal of Cleaner Production, 15(4), 347-356. http://dx.doi.org/10.1016/j.jclepro.2005.07.019.

Besiou, M., \& Van Wassenhove, L. N. (2015). Addressing the challenge of modeling for decision-making in socially responsible operations. Production and Operations Management, 24(9), 1390-1401. http://dx.doi.org/10.1111/poms.12375.

Blass, V., \& Corbett, C. J. (2018). Same supply chain, different models integrating perspectives from life cycle assessment and supply chain management. Journal of Industrial Ecology, 22(1), 18-30. http://dx.doi.org/10.1111/jiec. 12550.

Bourlakis, M., Maglaras, G., Gallear, D., \& Fotopoulos, C. (2014). Examining sustainability performance in the supply chain: The case of the Greek dairy sector. Industrial Marketing Management, 43(1), 56-66. http://dx.doi.org/10.1016/j.indmarman.2013.08.002.

Brancoli, P., Rousta, K., \& Bolton, K. (2017). Life cycle assessment of supermarket food waste. Resources, Conservation and Recycling, 118, 39-46. http://dx.doi.org/10.1016/j.resconrec.2016.11.024.

Brockhaus, S., Kersten, W., \& Knemeyer, A. M. (2013). Where do we go from here? Progressing Sustainability Implementation Efforts Across Supply Chains. J. Bus. Logist., 34, 167-182. http://dx.doi.org/10.1111/jbl.12017.

Carter, C. R., Meschnig, G., \& Kaufmann, L. (2015). Moving to the next level: Why our discipline needs more multilevel theorization. The Journal of Supply Chain Management, 51(4), 94-102. http://dx.doi.org/10.1111/jscm.12083.

Chang, D., Lee, C. K. M., \& Chen, C.-H. (2014). Review of life cycle assessment towards sustainable product development. Journal of Cleaner Production, 83, 48-60. http://dx.doi.org/10.1016/j.jclepro.2014.07.050. 
Corrado, S., Ardente, F., Sala, S., \& Saouter, E. (2017). Modelling of food loss within life cycle assessment: From current practice towards a systematisation. Journal of Cleaner Production, 14O(Part 2), 847-859. http://dx.doi.org/10.1016/j.jclepro.2016.06.050.

Djekic, 1., Miocinovic, J., Tomasevic, 1., Smigic, N., \& Tomic, N. (2014). Environmental life-cycle assessment of various dairy products. Journal of Cleaner Production, 68, 64-72. http://dx.doi.org/10.1016/j.jclepro.2013.12.054.

Doublet, G., Jungbluth, N., Stucki, M., \& Schori, S. (2013). Life cycle assessment of Romanian beef and dairy products (SENSE Project, No. 288974). Retrieved in 2014, October 26, from http://esu-services.ch/fileadmin/download/doublet-2013-SENSE_Deliverable2_1-LCAbeefdairy.pdf

Ecoinvent ${ }^{\circledR}$. (2014). Econivent DataBase. Version 3. Zurich, Switzerland: Ecoinvent.

Eide, M. H., Homleid, J. P., \& Mattsson, B. (2003). Life Cycle Assessment (LCA) of cleaning-in-place processes in dairies. LebensmittelWissenschaft + Technologie, 36(3), 303-314. http://dx.doi.org/10.1016/S0023-6438(02)00211-6.

ELCD $^{\circledR}$. (2014). DataBase. European Union: ELCD.

Galal, N. M., \& Moneim, A. F. A. (2016). Developing sustainable supply chains in developing countries. Procedia CIRP, 48, 419-424. http://dx.doi.org/10.1016/j.procir.2016.03.156.

Galo, N. R., Ribeiro, P. C. C., Mergulhão, R. C., \& Vieira, J. G. V. (2018). Selección de proveedor de servicios logísticos: alineación entre criterios e indicadores. Innovar, 28(69), 55-70. https://doi.org/10.15446/innovar.v28n69.71696.

Goedkoop, M., Heijungs, R., Huijbregts, M., De Schryver, A., Struijs, J. V. Z. R., \& Van Zelm, R. (2013). A life cycle impact assessment method which comprises harmonised category indicators at the midpoint and the endpoint level. The Hague: Ministry of VROM.

González-García, S., Castanheira, É. G., Dias, A. C., \& Arroja, L. (2013). Using Life Cycle Assessment methodology to assess UHT milk production in Portugal. The Science of the Total Environment, 442, 225-234. http://dx.doi.org/10.1016/j.scitotenv.2012.10.035. PMid:23178782.

Govindan, K. (2018). Sustainable consumption and production in the food supply chain: A conceptual framework. International Journal of Production Economics, 195, 419-431. http://dx.doi.org/10.1016/j.jpe.2017.03.003.

Gustavsson, J., Cederberg, C., Sonesson, U., van Otterdijk, R., \& Meybeck, A. (2011) Global food losses and food waste: Extent, causes and prevention. Rome: FA0. Retrieved in 2018, December 21, from http://www.fao.org/3/mb060e/mb060e00.pdf

Hagelaar, G. J. L. F., \& Van der Vorst, J. G. A. J. (2002). Environmental supply chain management: Using life cycle assessment to structure supply chains. The International Food and Agribusiness Management Review, 4(4), 399-412. http://dx.doi.org/10.1016/ S1096-7508(02)00068-X.

Hospido, A., Moreira, M. T., \& Feijoo, G. (2003). Simplified life cycle assessment of Galician milk production. International Dairy Journal, 13(10), 783-796. http://dx.doi.org/10.1016/S0958-6946(03)00100-6.

Hsu, C.-C., Tan, K.-C., \& Zailani, S. H. M. (2016). Strategic orientations, sustainable supply chain initiatives, and reverse logistics: Empirical evidence from an emerging market. International Journal of Operations \& Production Management, 36(1), 86-110. http://dx.doi. org/10.1108/1JOPM-06-2014-0252.

Hutchins, M. J., \& Sutherland, J. W. (2008). An exploration of measures of social sustainability and their application to supply chain decisions. Journal of Cleaner Production, 16(15), 1688-1698. http://dx.doi.org/10.1016/j.jclepro.2008.06.001.

Ingwersen, W., Gausman, M., Weisbrod, A., Sengupta, D., Lee, S.-J., Bare, J., Zanoli, E., Bhander, G. S., \& Ceja, M. (2016). Detailed life cycle assessment of Bounty ${ }^{\circledR}$ paper towel operations in the United States. Journal of Cleaner Production, 131, 509-522. http:// dx.doi.org/10.1016/j.jclepro.2016.04.149.

International Organization for Standardization (2006a). ISO 14040 - Environmental Management - Life Cycle Assessment - Principles and Framework. Geneva: 1SO.

International Organization for Standardization (2006b). ISO 14044 - Environmental Management - Life Cycle Assessment - Requirements and guidelines. Geneva: 1SO.

Jayaram, J., \& Avittathur, B. (2015). Green supply chains: A perspective from an emerging economy. International Journal of Production Economics, 164, 234-244. http://dx.doi.org/10.1016/j.jpe.2014.12.003.

Kang, S.-H., Kang, B., Shin, K., Kim, D., \& Han, J. (2012). A theoretical framework for strategy development to introduce sustainable supply chain management. Procedia: Social and Behavioral Sciences, 40, 631-635. http://dx.doi.org/10.1016/j.sbspro.2012.03.241.

Koh, S. C. L., Gunasekaran, A., Morris, J., Obayi, R., \& Ebrahimi, S. M. (2017). Conceptualizing a circular framework of supply chain resource sustainability. International Journal of Operations \& Production Management, 3710), 1520-1540. http://dx.doi.org/10.1108/ 1JOPM-02-2016-0078.

Kulak, M., Nemecek, T., Frossard, E., \& Gaillard, G. (2016). Eco-efficiency improvement by using integrative design and life cycle assessment. The case study of alternative bread supply chains in France. Journal of Cleaner Production, 112(Part 4), $2452-2461$. http://dx.doi.org/10.1016/j.jclepro.2015.11.002.

Martí, J. M. C., \& Seifert, R. W. (2013). Assessing the comprehensiveness of supply chain environmental strategies. Business Strategy and the Environment, 22, 339-356.

Mello, T. M., Eckhardt, D., \& Leiras, A. (2017). Sustainable procurement portfolio management: a case study in a mining company. Production Journal, 27(e20162136), 1-15. http://dx.doi.org/10.1590/0103-6513.213616.

Milani, F. X., Nutter, D., \& Thoma, G. (2011). Invited review: Environmental impacts of dairy processing and products: A review. Journal of Dairy Science, 94(9), 4243-4254. http://dx.doi.org/10.3168/jds.2010-3955. PMid:21854898.

Molina-Besch, K. (2016). Prioritization guidelines for green food packaging development. British Food Journal, 118(10), $2512-2533$. http://dx.doi.org/10.1108/BFJ-12-2015-0462.

Nepomuceno, R. S. C., Costa Junior, L. C. G., \& Costa, R. G. B. (2016). Exopolysaccharide-producing culture in the manufacture of Prato Cheese. Lebensmittel-Wissenschaft + Technologie, 72, 383-389. http://dx.doi.org/10.1016/j.lwt.2016.04.053.

Nigri, E. M., Barros, A. C., Rocha, S. D. F., \& Romeiro Filho, E. (2014). Assessing environmental impacts using a comparative LCA of industrial and artisanal production processes: "minas cheese" case. Food Science and Technology, 34(3), 522-531. http://dx.doi. $\operatorname{org} / 10.1590 / 1678-457 \times .6356$. 
Organisation for Economic Co-operation and Development \& Food and Agriculture Organization of the United Nations. (2018). Dairy and dairy products. In Organisation for Economic Co-operation and Development \& Food and Agriculture Organization of the United Nations. Agricultural Outlook 2018-2027. Paris: OECD/FAO. https://doi.org/10.1787/agr_outlook-2018-en

Pertusa-Ortega, E. M., López-Gamero, M. D., Pereira-Moliner, J., Tarí, J., \& Molina-Azorín, J. F. (2018). Antecedents of environmental management: the influence of organizational design and its mediating role between quality management and environmental management. Organization \& Environment, 31(4), 425-443. http://dx.doi.org/10.1177/1086026617718426.

Pré Sustainability. (2019). ReCiPe. Netherlands. Retrieved in 2015, February 10, from https://www.pre-sustainability.com/recipe

Roehrich, J. K., Hoejmose, S. U., \& Overland, V. (2017). Driving green supply chain management performance through supplier selection and value internalisation: A self-determination theory perspective. International Journal of Operations \& Production Management, 37(4), 489-509. http://dx.doi.org/10.1108/1JOPM-09-2015-0566.

Rohlfes, A. L. B., Baccar, N. M., Oliveira, M. S. R., Marquardt, L., \& Richards, N. S. P. S. (2011). Indústrias Lácteas: Alternativas de Aproveitamento do Soro de Leite como Forma de Gestão Ambiental. Tecni-Lógica, 15, 79-83. http://dx.doi.org/10.17058/tecnolog. v15i2.2350.

Sala, S., Anton, A., McLaren, S. J., Notarnicola, B., Saouter, E., \& Sonesson, U. (2017). In quest of reducing the environmental impacts of food production and consumption. Journal of Cleaner Production, 140, 387-398. http://dx.doi.org/10.1016/j.jclepro.2016.09.054.

Santos Junior, H. C. M., Maranduba, H. L., Almeida Neto, J. A., \& Rodrigues, L. B. (2017). Life cycle assessment of cheese production process in a small-sized dairy industry in Brazil. Environmental Science and Pollution Research International, $24(4), 3470-3482$. http://dx.doi.org/10.1007/s11356-016-8084-0. PMid:27873115.

Seles, B. M. R. P., Jabbour, A. B. L. S., Jabbour, C. J. C., \& Dangelico, R. M. (2016). The green bullwhip effect, the diffusion of green supply chain practices, and institutional pressures: Evidence from the automotive sector. International Journal of Production Economics, 182, 342-355. http://dx.doi.org/10.1016/j.ijpe.2016.08.033.

Shafiq, A., Johnson, P. F., Klassen, R. D., \& Awaysheh, A. (2017). Exploring the implications of supply risk on sustainability performance. International Journal of Operations \& Production Management, 3710), 1386-1407. http://dx.doi.org/10.1108/lJOPM-01-2016-0029.

SimaPro ${ }^{\circledR}$ (2014). SimaPro. Version 8.0.5.13. Netherlands: PRé Sustainability.

Tchokogué, A., Nollet, J., Merminod, N., Paché, G., \& Goupil, V. (2018). Is Supply’s Actual Contribution to Sustainable Development Strategic and Operational? Business Strategy and the Environment, 27(3), 336-358. http://dx.doi.org/10.1002/bse.2002.

Vagnoni, E., Franca, A., Porqueddu, C., \& Duce, P. (2017). Environmental profile of Sardinian sheep milk cheese supply chain: A comparison between two contrasting dairy systems. Journal of Cleaner Production, 165(1), 1078-1089. http://dx.doi.org/10.1016/j. jclepro.2017.07.115.

Vazquez-Rowe, 1., Hospido, A., Moreira, M.T., \& Feijoo, G., 2012. Best practices in life cycle assessment implementation in fisheries. Improving and broadening environmental assessment for seafood production systems. Trends in Food Science \& Technology, 28(2), 116-131. http://dx.doi.org/10.1016/j.tifs.2012.07.003.

Wang, Q., Qiu, S., Yuan, X., Zuo, J., Cao, D., Hong, J., Zhang, J., Dong, Y., \& Zheng, Y. (2016). Stability of ecological industry chain: An entropy model approach. Environmental Science and Pollution Research International, 23(14), 14316-14326. http://dx.doi. org/10.1007/s11356-016-6579-3. PMid:27055893.

Zhong, R., Xu, X., \& Wang, L. (2017). Food supply chain management: Systems, implementations, and future research. Industrial Management \& Data Systems, 117(9), 2085-2114. http://dx.doi.org/10.1108/IMDS-09-2016-0391. 